\title{
Comparative Effects In Vivo of Recombinant Murine Interleukin 3, Natural Murine Colony-stimulating Factor-1, and Recombinant Murine Granulocyte-Macrophage Colony-stimulating Factor on Myelopoiesis in Mice
}

\author{
Hal E. Broxmeyer,"* Douglas E. Williams, " Scott Cooper," Richard K. Shadduck," \\ Steven Gillis," Abdul Waheed," David L. Urdal," and David C. Bicknell* \\ Departments of ${ }^{*}$ Medicine (Hematology/Oncology), ${ }^{\ddagger}$ Microbiology and Immunology, Indiana University School of Medicine, Walther \\ Medical Research Institute and Elks Cancer Center, Indianapolis, Indiana 46223; ' Department of Medicine, Montefiore Hospital, \\ University of Pittsburgh School of Medicine, Pittsburgh, Pennsylvania 15213; and "Department of Research and Development, \\ Immunex Corporation, Seattle, Washington 98101
}

\begin{abstract}
Purified murine colony-stimulating factors (CSF) recombinant interleukin 3 (IL-3), natural CSF-1, and recombinant granulocyte-macrophage (GM) CSF were assessed in vivo for their effects on BDF 1 mouse bone marrow and spleen granulocyte-macrophage (CFU-GM), erythroid (BFU-E), and multipotential (CFU-GEMM) progenitor cells in untreated mice and in mice pretreated with purified iron-saturated human lactoferrin (LF). The CSF and LF preparations did not contain detectable endotoxin ( $<0.1 \mathrm{ng}$ ). Mice pretreated with LF were more sensitive to the effects of CSF. In mice pretreated with LF, 2,000 U IL-3 or 20,000 U CSF-1 significantly enhanced the cycling status and absolute numbers of all progenitors, whereas 20,000 U GMCSF significantly increased the cycling status of CFU-GM and CFU-GEMM, but had no effect on cycling of BFU-E or on numbers of any of the progenitors. The effects of CSF in mice pretreated with LF were not mimicked by 0.1-100 ng $E$. coli lipopolysaccharide.
\end{abstract}

\section{Introduction}

Colony-stimulating factors $(\mathrm{CSF})^{1}$ were originally defined based on their capacity to stimulate colony formation by hematopoietic

These studies were presented at the 27th Annual Meeting of the American Society of Hematology, New Orleans, LA in December 1985, the International Symposium on Biological Regulation of Cell Proliferation and Ninth International Chalone Conference, Milan, Italy in March 1986, the International Conference on Cytokines, Erlangen, FRG in March 1986, and the 15th Annual Meeting of the International Society for Experimental Hematology in Buffalo, NY in August 1986, and appeared in abstract form in 1985 (Blood. [66 Suppl. 1]:146a) and 1986 (Exp. Hematol. 14:418).

Received for publication 29 July 1986.

1. Abbreviations used in this paper: BFU-E, burst-forming unit, erythroid; BPA, burst-promoting activity; CFU-GEMM, colony-forming unit, granulocyte-erythroid-macrophage-megakaryocyte; CFU-GM, colonyforming unit, granulocyte-macrophage; $\mathrm{CM}$, conditioned medium; CSF, colony-stimulating factor; CSF-1, macrophage CSF; GM-CSF, granulocyte-macrophage CSF; ${ }^{3} \mathrm{HTdR}$, tritiated thymidine; IL-3, interleukin 3; LF, lactoferrin; LPS, lipopolysaccharide; PWMSCM, pokeweed mitogen mouse spleen cell $\mathrm{CM}$.

J. Clin. Invest.

(C) The American Society for Clinical Investigation, Inc.

$0021-9738 / 87 / 03 / 0721 / 10 \quad \$ 1.00$

Volume 79, March 1987, 721-730 progenitor cells in semisolid culture medium $(1,2)$. Included in this group of factors are interleukin 3 (IL-3), also referred to as multi-CSF, CSF-2 $\alpha$, P-cell-stimulating factor, hemopoietin-2, burst promoting activity (BPA), 20 $\alpha$ hydroxysteroid-inducing activity, WEHI-3 growth factor, Thy-1-inducing activity, colonyforming unit-spleen-stimulating activity, and hematopoietic cell growth factor), macrophage CSF (CSF-1), granulocyte-macrophage (GM)-CSF, and granulocyte (G)-CSF (1, 2). IL-3 (3-6), pluripotent CSF (7), pluripoietin $\alpha$ (8), CSF-1 (9-12), GM-CSF $(5,13)$, and G-CSF (14) have been purified to homogeneity, and more recently the complementary DNA (cDNA) and/or genes for IL-3 (15-18), CSF-1 (19), GM-CSF (20-23), and G-CSF/ pluripotent CSF $(24,25)$ have been cloned and expressed. The receptors and receptor-binding for IL-3 (26-28), CSF-1 (27, 29$36)$, GM-CSF $(27,37-39)$, and G-CSF $(27,40)$ have been studied and it is clear that in addition to their effects on hematopoietic progenitor cells $(1,2)$, they also influence the functioning of more mature cells (reviewed in references 41 and 42; 43-48). The possible involvement of the genes for some of these factors and their receptors in myeloid disorders has been suggested (49, 50). Although there is now a wealth of information on the actions of these molecules in vitro, a paucity of information is available describing an activity for these purified molecules in vivo. The reports published are only for IL-3 and GM-CSF using mainly multiple or continuous infusions of high concentrations of these factors (51-54).

The present studies were undertaken to compare the short term effects in vivo of relatively low concentrations of purified preparations of recombinant murine IL-3, natural murine CSF1 , and recombinant murine GM-CSF on the numbers of nucleated cells, the number of granulocyte-macrophage (CFUGM), erythroid (BFU-E), and multipotential (CFU-GEMM) progenitor cells and the cycling status of these progenitors in the bone marrows and spleens of mice. Lactoferrin (LF), which suppresses the release of growth factors in vitro (55-60) and myelopoiesis in vivo $(61,62)$, was used as a tool to increase the sensitivity in vivo of the mice to the effects of exogenously administered IL-3, CSF-1, and GM-CSF.

\section{Methods}

Mice. $(\mathrm{C} 57 \mathrm{BL} / 6 \times \mathrm{DBA} / 2) \mathrm{F}_{1}\left(\mathrm{BDF}_{1}\right)$ mice, $6-8 \mathrm{wk}$ old, were purchased from Cumberland View Farms (Clinton, TN).

Molecules. Murine IL-3 and GM-CSF were expressed from cloned cDNA prepared from RNA extracted from LBRM-33-5A4 cells. The two cDNA clones had nucleotide sequences that were essentially identical to those reported by others for their respective factors $(28,38)$. The factors were produced in a yeast expression system that used the prepro 
$\alpha$-factor promoter and leader sequence to direct secretion of the mature forms of the factors $(28,38)$. The expressed IL-3 and GM-CSF were purified using reversed-phase high-performance liquid chromatography. IL-3 had a specific activity of $10^{9} \mathrm{U} / \mathrm{mg}$ protein when titered against the IL-3-dependent murine cell line FDC-P2 (28). Units of IL-3 were determined as the reciprocal dilution of a sample that generated $50 \%$ of maximal FDC-P2 $\left[{ }^{3} \mathrm{H}\right]$ thymidine incorporation as compared with a laboratory standard (WEHI-3b cell line conditioned medium). Therefore, if a sample stimulated $50 \%$ of maximal FDC-P2 $\left[{ }^{3} \mathrm{H}\right]$ thymidine incorporation at a dilution of $1: 10,10 \%$ of $100 \mu \mathrm{l}$ (assay volume) or $10 \mu \mathrm{l}$ contained $1 \mathrm{U}$. GM-CSF had a specific activity of $10^{8} \mathrm{U} / \mathrm{mg}$ protein based upon mouse bone marrow colony formation (38). Units of GMCSF were determined using $10^{5}$ mouse marrow cells in $1 \mathrm{ml}$ and finding the dilution of sample which gave $50 \%$ maximal colony numbers. The $50 \%$ maximal number of colonies was then multiplied by the reciprocal of the sample dilution to yield number of CFU-GM per milliliter. L-cell CSF (CSF-1) was produced by the growth of murine L-cells in serumfree CMRL 1066 medium as described previously (10). A liter pool of conditioned medium (CM) was purified by affinity chromatography (11) and had a specific activity of $2.3 \times 10^{7} \mathrm{U} / \mathrm{mg}$ of protein when assayed by the in vitro growth of murine bone marrow colonies. CSF-1 activity was calculated from the linear portion of the dilution curve of $10^{5}$ mouse bone marrow cells where formation of one colony was defined as $1 \mathrm{U}$ of CSF-1. This material was subjected to sucrose density gradient centrifugation as a means of removing any potential endotoxin (63). After centrifugation at $100,000 \mathrm{~g}$ for $18 \mathrm{~h}$, the upper third of the sucrose gradient was aspirated and diluted in $0.1 \mathrm{M}$ Tris $\mathrm{HCl}$ containing $0.3 \%$ polyethylene glycol as a stabilizing agent. A control solution was prepared using the upper third of a sucrose density gradient that did not contain CSF. Human milk LF, purchased from Sigma Chemical Co., St. Louis, MO, was purified, fully iron saturated $(55,60)$, and depleted of endotoxin by removing the material that gelled in the presence of the Limulus lysate (Sigma Chemical Co.) (64). LF was quantified using an immunoradiometric assay for LF prior to use (60). Injections of factors to mice were in a volume of $0.2 \mathrm{ml}$. By using the Limulus lysate test for endotoxin, which has a sensitivity range down to $0.5 \mathrm{ng} / \mathrm{ml}$, we detected no endotoxin $(<0.1 \mathrm{ng} / \mathrm{ml})$ in the preparations of IL-3, GM-CSF, CSF-1, or LF. $E$. coli lipopolysaccharide was purchased from Sigma Chemical Co.

Analysis of hematopoietic progenitor cells in vitro. The assay for CFUGM was performed as described (65) with the purified preparations of recombinant IL-3, natural CSF-1, recombinant GM-CSF and pokeweed mitogen mouse spleen cell conditioned medium (PWMSCM) as sources of CSF (65). Granulocyte-macrophage colony formation (> 50 cells/ aggregate) from cells taken from mice pretreated with the purified preparation of CSF and/or LF, was evaluated using 10\% vol/vol PWMSCM as a stimulus. Clusters (3-50 cells) were scored also. As the results for colonies and clusters were similar to those for colonies, the results are only shown for colonies. Bone marrow and spleen cells were plated respectively at $7.5 \times 10^{4}$ and $1.0 \times 10^{6}$ cells $/ \mathrm{ml}$ in $0.3 \%$ agar culture medium (Difco Laboratories Inc., Detroit, MI) that included McCoy's 5A medium supplemented with essential and nonessential amino acids, glutamine, serine, asparagine, and sodium pyruvate (Gibco Laboratories, Grand Island, NY), with $10 \%$ prescreened heat-inactivated $\left(56^{\circ} \mathrm{C}\right.$ for $\left.0.5 \mathrm{~h}\right)$ fetal bovine serum (FBS) (HyClone Laboratories, Logan, UT). Unless otherwise noted, colonies were scored after 6-7 d of incubation.

For colony morphology, agar cultures were overlaid with $1 \mathrm{ml}$ of $0.5 \%$ glutaraldehyde (Sigma Chemical Co.) in $0.1 \mathrm{M}$ phosphate buffer. After $6 \mathrm{~min}$, glutaraldehyde was removed and $2 \mathrm{ml}$ absolute methanol was added to the plates. After the methanol evaporated (12-18 h) the fixed cultures were submerged in distilled water. After rehydration, the agar pellicles were floated onto clean glass slides and allowed to dry. For identification of granulocytes and monocytes/macrophages, colonies were stained for 45 min with -naphthyl acetate esterase (Sigma Kit \#90-A1) and counterstained with Mayer's hematoxylin for $10 \mathrm{~min}$. Slides were washed, dried at room temperature, mounted (Permount, Fisher Scientific Co., St. Louis, MO), and scored at $400 \times$. Monocytes/macrophages were enumerated based on their morphology and the characteristic black cytoplasmic granulation.
The assay for BFU-E-2 was plated at $1 \times 10^{5} \mathrm{cells} / \mathrm{ml}$ for marrow and $1 \times 10^{6} \mathrm{cells} / \mathrm{ml}$ for spleen in a $1-\mathrm{ml}$ mixture of Iscove's modified Dulbecco's medium (Gibco Laboratories), $0.8 \%$ methylcellulose, $30 \%$ prescreened FBS (HyClone Laboratories), $5 \times 10^{-5} \mathrm{M} 2$-mercaptoethanol, $1 \mathrm{U}$ of erythropoietin (HyClone Laboratories) and $0.1 \mathrm{mM}$ Hemin (Eastman Kodak Co., Rochester, NY). Hemin increases colony formation by BFU-E and CFU-GEMM (66). BFU-E-1 and CFU-GEMM assays were scored from the same plates and were set up as for BFU-E-2 except that $1 \% \mathrm{v} / \mathrm{v}$ PWMSCM was added. Cells were plated at $7.5 \times 10^{4} \mathrm{cells} / \mathrm{ml}$ for bone marrow and $1 \times 10^{6}$ cells/ml for spleen BFU-E-1 and CFUGEMM assays. BFU-E-2, BFU-E-1, and CFU-GEMM assays were scored after 6-7 d of incubation. BFU-E-2 colonies contained at least 50 cells or were composed of at least three subcolonies containing a minimum of 10 cells each, whereas colonies derived from BFU-E-1 were much larger than those derived from BFU-E-2. BFU-E-1 may represent a more immature progenitor than BFU-E-2, although this has not been proven. Cells were incubated in a humidified environment at lowered (5\%) oxygen tension. Low oxygen tension was maintained using an Oxyreducer (Reming Bioinstruments, Rochester, NY) because lowered oxygen tension increases the incidence of colonies derived from hematopoietic progenitor cells (67).

Cycle status of hematopoietic progenitor cells. To estimate the proportion of progenitors in DNA synthesis (S-phase), cells were treated with either McCoy's medium or $50 \mu \mathrm{Ci} / \mathrm{ml}$ tritiated thymidine $\left({ }^{3} \mathrm{HTdR}\right)$ diluted in McCoy's medium (New England Nuclear, Boston, MA, specific activity, $20 \mathrm{Ci} / \mathrm{mmol}$ ). After a 20 -min incubation at $37^{\circ} \mathrm{C}$, the cells were washed once in phosphate-buffered saline containing ice cold thymidine $(2,000 \mu \mathrm{g})$, twice more in McCoy's medium, and then plated into the CFU-GM, BFU-E, and CFU-GEMM assays. The reduction in the number of colonies after exposure of cells to ${ }^{3} \mathrm{HTdR}$ compared with control (McCoy's medium) estimates the proportion of progenitor cells in cycle just before assaying for colony formation. The results are given as the percent of cells in S-phase. A negative number means that more colonies formed after cells were exposed to tritiated thymidine than after cells were exposed to McCoy's medium. In some select cases, cells were also exposed to $500 \mu \mathrm{g}$ thymidine, or $50 \mu \mathrm{Ci}{ }^{3} \mathrm{HTdR}$ plus $500 \mu \mathrm{g}$ thymidine as controls for the S-phase specificity of the treatments. In all cases, the numbers of colonies formed were statistically similar whether cells were exposed to McCoy's medium, thymidine, or ${ }^{3} \mathrm{HTdR}$ plus thymidine. The percentage of cells in S-phase was based on control colony counts that were in the range of $30-165,15-39,20-45$, and $15-36$, respectively for the CFU-GM, BFU-E-2, BFU-E-1, and CFU-GEMM assays.

Experimental protocols. The details of these are described in the results section and in the tables. After sacrifice, the marrow from the two femurs of each mouse was pooled. This marrow and the spleen of each mouse were assayed' separately. Cells from different mice were not pooled. Three to four mice per group were used in each experiment unless otherwise noted in the text or in the table legends.

Statistical analysis. Three plates were scored for each CFU-GM sample and two plates were scored for each BFU-E-2 or BFU-E-1/CFUGEMM sample. The results are expressed as the mean \pm 1 SEM and these are derived from the averages of the colony counts from each of the individual mice within a group. The probability of significant differences between groups or samples was determined with the use of Student's $t$ test.

\section{Results}

Influence of colony-stimulating factors in vitro. Before assessing the actions of IL-3, CSF-1, and GM-CSF in vivo, these growth factors were compared for their capacity to stimulate colony formation by bone marrow CFU-GM, BFU-E-1, and CFUGEMM (Table I). IL-3 contained GM-CSF, BPA, and multiCSF activities, but the GM-CSF activity in the IL-3 preparation was relatively low compared with the other activities on a unit basis. Both CSF-1 and GM-CSF-stimulated colony formation 
Table I. Influence of Pure Natural Murine CSF-1,

Pure Recombinant Murine GM-CSF, and

Pure Recombinant Murine IL-3 on Colony

Formation by CFU-GM, BFU-E and CFU-GEMM

\begin{tabular}{|c|c|c|c|c|}
\hline \multirow[b]{2}{*}{ Test material } & \multirow[b]{2}{*}{ Units } & \multicolumn{3}{|c|}{ Colonies ( $\bar{x} \pm 1$ SEM) } \\
\hline & & CFU-GM & BFU-E-1 & CFU-GEMM \\
\hline \multirow{8}{*}{$\begin{array}{l}\text { McCoy's medium } \\
\text { IL-3 }\end{array}$} & & 0 & $18 \pm 2$ & $1 \pm 0$ \\
\hline & 10 & 0 & $17 \pm 1$ & $1.5 \pm 0.5$ \\
\hline & 25 & 0 & $16 \pm 1$ & $2.5 \pm 0.5$ \\
\hline & 50 & 0 & $19 \pm 3$ & $4 \pm 1$ \\
\hline & 100 & $0.3 \pm 0.3$ & $18 \pm 2$ & $7 \pm 1$ \\
\hline & 200 & $2 \pm 0.6$ & $22 \pm 2$ & $6 \pm 1$ \\
\hline & 400 & $4 \pm 0.3$ & $28 \pm 2$ & $10 \pm 2$ \\
\hline & 800 & $7 \pm 1$ & $33 \pm 1$ & $10 \pm 1$ \\
\hline \multirow[t]{5}{*}{ CSF-1 } & 10 & $16 \pm 1$ & $15 \pm 3$ & $1.5 \pm 0.5$ \\
\hline & 25 & $54 \pm 4$ & $16 \pm 3$ & $0.5 \pm 0.5$ \\
\hline & 50 & $119 \pm 6$ & $10 \pm 2$ & $0.5 \pm 0.5$ \\
\hline & 100 & $159 \pm 6$ & $8 \pm 1$ & 0 \\
\hline & 200 & TNC & $6 \pm 2$ & 0 \\
\hline \multirow[t]{7}{*}{ GM-CSF } & 10 & 0 & $14 \pm 2$ & $1 \pm 1$ \\
\hline & 25 & $5 \pm 1$ & $15 \pm 1$ & $1 \pm 0$ \\
\hline & 50 & $10 \pm 1$ & $14 \pm 4$ & $1.5 \pm 0.5$ \\
\hline & 100 & $25 \pm 1$ & $15 \pm 3$ & $1 \pm 0$ \\
\hline & 200 & $47 \pm 3$ & $13 \pm 2$ & $0.5 \pm 0.5$ \\
\hline & 400 & $45 \pm 1$ & $16 \pm 2$ & $1 \pm 0$ \\
\hline & 800 & $54 \pm 5$ & $15 \pm 1$ & $1 \pm 0$ \\
\hline
\end{tabular}

$\mathrm{BDF}_{1}$ bone marrow cells were plated at $7.5 \times 10^{4} / \mathrm{ml}$ and scored after $7 \mathrm{~d}$ of incubation at $5 \% \mathrm{O}_{2}$ and $5 \% \mathrm{CO}_{2}$. BFU-E and CFU-GEMM assays were plated in presence of $1 \mathrm{U}$ erythropoietin and $0.1 \mathrm{mM}$ hemin. Units of activity for the purified preparations of IL-3, GMCSF, and CSF-1 were derived as described elsewhere $(11,28,38)$. Differences between the units quoted above and the actual numbers of CFU-GM colonies stimulated most likely reflect different culture conditions between laboratories and the use of marrow cells from different strains of mice. TNC, too numerous to count.

of CFU-GM, but neither contained BPA or mixed colony activities at concentrations that were plateau for stimulation of CFU-GM. IL-3 and GM-CSF-stimulated colony and cluster formation of granulocytes, macrophages, and granulocytes plus macrophages after 4 and $7 \mathrm{~d}$ of incubation (data not shown). While CSF-1 stimulated mainly macrophage colonies after $7 \mathrm{~d}$ of incubation, colonies of granulocytes, macrophages, and granulocytes plus macrophages were stimulated by CSF-1 when colonies were scored after $4 \mathrm{~d}$ of incubation (Table II). The results shown in Tables I and II have been reproduced in at least three different experiments.

Effects of IL-3 in vivo. IL-3 was assessed for effects on the cycling status of bone marrow CFU-GM in mice pretreated with sterile pyrogen-free saline or with endotoxin-depleted iron-saturated human LF. Mice were given saline or $100 \mu \mathrm{g} \mathrm{LF} \mathrm{i.v.} \mathrm{and}$ were inoculated i.v. $15 \mathrm{~h}$ later with $500 \mathrm{U}$ IL-3 or control diluent. The cycling status of control mice given saline and control diluent was similar to that of mice not previously injected with any material (30-40\% of CFU-GM in S-phase). In two separate experiments, LF significantly decreased $(P<0.0001)$ the percent of CFU-GM in S-phase from $31 \pm 4$ and $30 \pm 5 \%$ to $4 \pm 9$ and $-4 \pm 2 \%$. IL-3 significantly increased $(P<0.005)$ the percent of
Table II. Influence of Purified Mouse CSF-1 and PWMSCM on Colony Formation by BDF, Mouse Bone Marrow Cells

\begin{tabular}{|c|c|c|c|c|}
\hline \multirow[b]{2}{*}{ Stimulus } & \multirow[b]{2}{*}{$\begin{array}{l}\text { Colonies per } \\
7.5 \times 10^{4} \text { cells }\end{array}$} & \multicolumn{3}{|c|}{ Colony morphology as a percent } \\
\hline & & Granulocyte & Macrophage & $\begin{array}{l}\text { Granulocyte- } \\
\text { macrophage }\end{array}$ \\
\hline \multicolumn{5}{|c|}{ Plates scored after $4 \mathrm{~d}$ of incubation } \\
\hline 100 U CSF-1 & $90 \pm 3$ & 12 & 60 & 28 \\
\hline 50 U CSF-1 & $93 \pm 7$ & 17 & 48 & 35 \\
\hline 25 U CSF-1 & $57 \pm 6$ & 23 & 58 & 19 \\
\hline \multicolumn{5}{|l|}{$5 \% \mathrm{vol} / \mathrm{vol}$} \\
\hline PWMSCM* & $70 \pm 5$ & 33 & 42 & 25 \\
\hline \multicolumn{5}{|c|}{ Plates scored after $7 \mathrm{~d}$ of incubation } \\
\hline 100 U CSF-1 & $146 \pm 6$ & 3 & 84 & 13 \\
\hline 50 U CSF-1 & $121 \pm 6$ & 5 & 79 & 16 \\
\hline 25 U CSF-1 & $95 \pm 4$ & 11 & 61 & 28 \\
\hline \multicolumn{5}{|l|}{$5 \% \mathrm{vol} / \mathrm{vol}$} \\
\hline PWMSCM* & $78 \pm 1$ & 42 & 19 & 39 \\
\hline
\end{tabular}

* PWMSCM is used for comparison with the effects of CSF-1 on colony formation.

CFU-GM in S-phase to $59 \pm 4$ and $54 \pm 4 \%$ in mice pretreated with saline. The stimulatory effect of IL-3 was even more apparent when the percent of CFU-GM in S-phase in mice given both LF and IL-3 (51 \pm 2 and $52 \pm 6 \%)$ was compared with the percent of CFU-GM in S-phase in mice given LF and then control diluent ( $4 \pm 9$ and $-4 \pm 2 \%$ ).

Since LF decreases the cycling status and absolute numbers of marrow CFU-GM, BFU-E, and CFU-GEMM when administered to mice $(55,61,62)$, and pretreatment of mice with $\mathrm{LF}$ resulted in a more sensitive assay for detection of the effects of IL-3 in vivo, the rest of the studies with IL-3 were done by evaluating the effects of IL-3 in mice pretreated with $50 \mu \mathrm{g} \mathrm{LF}$, which was as effective as $100 \mu \mathrm{g}$ LF (data not shown). In LFpretreated mice, $500 \mathrm{U}$ IL-3 increased the cycling status of bone marrow CFU-GM, BFU-E-2, BFU-E-1, and CFU-GEMM within $3 \mathrm{~h}$ of IL-3 administration (Table III). This effect was still apparent after $24 \mathrm{~h}$, but was decreased substantially by $48 \mathrm{~h}$ (Table III). IL-3 (500 U) increased the absolute numbers of BFUE and CFU-GEMM, but not CFU-GM, within 24-48 h, with no significant effect within 3-48 h noted on the total nucleated marrow cell population (Table III).

A dose response study of IL-3 on marrow (Table IV) and splenic (Table V) hematopoiesis within $22 \mathrm{~h}$, after IL-3 administration to LF-pretreated mice, demonstrated that 2,000 U of IL-3 increased the absolute numbers and cycling status of both femoral and splenic CFU-GM, BFU-E-2, BFU-E-1, and CFUGEMM, without a detectable effect on the total nucleated cellularity of these organs (Tables IV and V) or on the peripheral blood cell counts (data not shown). The dose response data in Tables IV and V demonstrate also that: (a) BFU-E and CFUGEMM are more sensitive to the effects of IL-3 in vivo than are CFU-GM, (b) cycling status of progenitors is a more sensitive parameter than progenitor cell numbers for detecting the effects of IL-3, and $(c)$ the marrow is a more sensitive target organ than the spleen to the hematopoietic enhancing effects of IL-3 in mice pretreated with LF.

Effects of CSF-1 in vivo. To determine if pretreatment of 
Table III. Influence of Purified Recombinant Mouse IL-3 In Vivo on Nucleated Cells, Hematopoietic Progenitor Cells, and Cycling of Progenitors in Mice Pretreated with Lactoferrin

\begin{tabular}{|c|c|c|c|c|c|c|c|c|c|}
\hline \multirow[b]{2}{*}{ Test material } & \multirow{2}{*}{$\begin{array}{l}\text { Nucleated cells } \\
\times 10^{-6} / \mathrm{femur}\end{array}$} & \multicolumn{4}{|c|}{ Colonies $\times 10^{-3} /$ femur $(\% \Delta)$} & \multicolumn{4}{|c|}{ Percent of cells in S-phase } \\
\hline & & CFU-GM & BFU-E-2 & BFU-E-1 & CFU-GEMM & CFU-GM & BFU-E-2 & BFU-E-1 & CFU-GEMM \\
\hline \multicolumn{10}{|c|}{ Exp. $1 \mathrm{LF}, 12 \mathrm{~h}$ later test material, $3 \mathrm{~h}$ later sacrifice mice } \\
\hline Control diluent & $17.7 \pm 3.9$ & $24.2 \pm 4.3$ & $2.7 \pm 0.4$ & $3.2 \pm 0.5$ & $2.1 \pm 0.9$ & $16 \pm 3$ & $3 \pm 8$ & $4 \pm 7$ & $9 \pm 6$ \\
\hline IL-3 (500 U) & $18.5 \pm 4.0(+5)$ & $29.1 \pm 8.8(+20)$ & $3.1 \pm 0.6(+15)$ & $3.5 \pm 0.6(+9)$ & $2.6 \pm 0.4(+24)$ & $53 \pm 7^{*}$ & $67 \pm 8^{*}$ & $47 \pm 8^{*}$ & $59 \pm 11^{*}$ \\
\hline \multicolumn{10}{|c|}{ Exp. $2 \mathrm{LF}, 12 \mathrm{~h}$ later test material, $24 \mathrm{~h}$ later sacrifice mice } \\
\hline Control diluent & $15.3 \pm 1.3$ & $24.0 \pm 0.3$ & $2.6 \pm 0.4$ & $1.1 \pm 0.1$ & $1.2 \pm 0.2$ & $15 \pm 2$ & $21 \pm 3$ & $13 \pm 3$ & $10 \pm 5$ \\
\hline IL-3 (500 U) & $15.5 \pm 1.7(+1)$ & $27.2 \pm 4.0(+13)$ & $4.0 \pm 0.4(+54)^{*}$ & $2.0 \pm 0.2(+82)^{*}$ & $2.5 \pm 0.6(+108)^{*}$ & $43 \pm 1^{*}$ & $59 \pm 7^{*}$ & $45 \pm 6^{*}$ & $58 \pm 3^{*}$ \\
\hline \multicolumn{10}{|c|}{ Exp. $3 \mathrm{LF}, 12 \mathrm{~h}$ later test material, $48 \mathrm{~h}$ later sacrifice mice } \\
\hline Control diluent & $20.8 \pm 0.4$ & $16.1 \pm 0.5$ & $3.0 \pm 0.1$ & $5.1 \pm 0.7$ & $1.1 \pm 0.1$ & $32 \pm 6$ & $35 \pm 6$ & $12 \pm 12$ & $2 \pm 14$ \\
\hline IL-3 (500 U) & $20.3 \pm 0.4(-2)$ & $18.6 \pm 14(+16)$ & $4.9 \pm 0.7(+63)^{*}$ & $7.3 \pm 1.0(+43)$ & $2.3 \pm 0.2(+109)^{*}$ & $41 \pm 3$ & $58 \pm 2 *$ & $25 \pm 6$ & $45 \pm 2^{*}$ \\
\hline
\end{tabular}

Mice were pretreated with $50 \mu \mathrm{g}$ endotoxin-depleted human lactoferrin i.v. and then treated i.v. with control diluent or IL-3 as described. Each experiment is the average of three mice per group. Numbers in parentheses designate the percent change $(\% \Delta)$ from control. * Significant percent change $(\% \Delta)$ from mice injected with control diluent, $P<0.05$.

mice with LF also made them more sensitive to the effects of CSF-1, mice were given sterile pyrogen-free saline or $100 \mu \mathrm{g} \mathrm{LF}$ i.v. and were injected i.v. $15 \mathrm{~h}$ later with $20,000 \mathrm{U}$ CSF-1 or control diluent. Mice were sacrificed $3 \mathrm{~h}$ later. In two experiments, LF significantly decreased $(P<0.001)$ the percent of marrow CFU-GM in S-phase from $35 \pm 5 \%$ and $40 \pm 2 \%$ to $-2 \pm 10 \%$ and $-8 \pm 4 \%$. CSF-1 significantly increased $(P<0.005)$ the percent of CFU-GM in S-phase to $66 \pm 4$ and $61 \pm 2 \%$ in mice pretreated with saline. The stimulating effect of CSF-1 was even more apparent when the percent of CFU-GM in S-phase in mice given both LF and CSF-1 (62 $10 \%$ and $63 \pm 8 \%)$ was compared to the percent of CFU-GM in S-phase in mice given LF and then control diluent $(-2 \pm 10 \%$ and $-8 \pm 4 \%)$.

A time sequence study evaluating the effects of CSF-1 in LF-pretreated mice (Table VI, experiments 1-4) demonstrated that $20,000 \mathrm{U}$ of CSF-1 increased the cycling status of bone marrow CFU-GM, BFU-E-2, BFU-E-1, and CFU-GEMM within $3 \mathrm{~h}$, with this increase still apparent after 12 and $24 \mathrm{~h}$. By $48 \mathrm{~h}$, the cycle enhancing effects of CSF-1 were no longer apparent. CSF-1 caused increases in the absolute numbers of these progenitors by 12-24 $\mathrm{h}$ with no detectable effect apparent by $48 \mathrm{~h}$. Because the suppressive effects of LF in vivo are lost with time (60), mice were given sequential treatments with LF and CSF-1 (Table VI, experiment 5) and the mice were evaluated $24 \mathrm{~h}$ after the second injection with CSF-1, which was $39 \mathrm{~h}$ after the first administration of CSF-1. These mice received a total dosage of $100 \mu \mathrm{g} \mathrm{LF}$ and 40,000 U CSF-1. Under these conditions both the cycling status and absolute numbers of marrow progenitors were enhanced significantly. No significant effect on total nucleated cellularity was apparent in the five separate experiments shown in Table VI.

By assessing the marrow and splenic effects of varying concentrations of CSF-1 given to mice pretreated with LF (Tables VII and VIII) it was apparent that CSF-1, at concentrations of 10,000 and $20,000 \mathrm{U}$, significantly increased the percent of marrow and splenic CFU-GM, BFU-E-2, BFU-E-1, and CFUGEMM that were in S-phase. CFU-GM were more sensitive to the effects of CSF-1 than were BFU-E and CFU-GEMM (Tables

Table IV. Influence of Purified Recombinant Murine IL-3 In Vivo on the Numbers of Femoral Nucleated Cells, Hematopoietic Progenitor Cells, and the Cycling Status of Progenitor Cells in Mice Pretreated with Lactoferrin

\begin{tabular}{|c|c|c|c|c|c|c|c|c|c|}
\hline \multirow[b]{2}{*}{ Test material } & \multirow{2}{*}{$\begin{array}{l}\text { Nucleated cells } \\
\times 10^{-6} / \mathrm{femur}\end{array}$} & \multicolumn{4}{|c|}{ Colonies $\times 10^{-3} /$ femur $(\% \Delta)$} & \multicolumn{4}{|c|}{ Percent of cells in S-phase } \\
\hline & & CFU-GM & BFU-E-2 & BFU-E-1 & CFU-GEMM & CFU-GM & BFU-E-2 & BFU-E-1 & CFU-GEMM \\
\hline Control medium & $15.5 \pm 0.8$ & $13.1 \pm 1.0$ & $5.0 \pm 0.5$ & $2.5 \pm 0.1$ & $3.0 \pm 0.2$ & $21 \pm 4$ & $14 \pm 5$ & $9 \pm 5$ & $2 \pm 3$ \\
\hline 2,000 U IL-3 & $15.8 \pm 0.7(+2)$ & $17.9 \pm 0.8(+37)^{*}$ & $8.1 \pm 0.4(+62)^{*}$ & $3.8 \pm 0.2(+52)^{*}$ & $5.0 \pm 0.3(+67)^{*}$ & $63 \pm 3^{*}$ & $61 \pm 3^{*}$ & $54 \pm 3^{*}$ & $59 \pm 2 *$ \\
\hline 1,000 U IL-3 & $12.8 \pm 0.8(-17)$ & $10.7 \pm 0.8(-18)$ & $5.4 \pm 0.1(+8)$ & $3.8 \pm 0.7(+52)^{\ddagger}$ & $4.8 \pm 0.2(+60)^{*}$ & $47 \pm 2^{*}$ & $55 \pm 6^{*}$ & $44 \pm 4^{*}$ & $50 \pm 3^{*}$ \\
\hline 500 U IL-3 & $13.7 \pm 0.6(-12)$ & $10.2 \pm 2.7(-22)$ & $5.3 \pm 0.8(+6)$ & $3.2 \pm 0.2(+28)^{\ddagger}$ & $3.6 \pm 0.1(+20)^{\ddagger}$ & $45 \pm 8^{*}$ & $54 \pm 1^{*}$ & $50 \pm 4^{*}$ & $66 \pm 8^{*}$ \\
\hline 250 U IL-3 & $16.1 \pm 0.1(+4)$ & $11.4 \pm 0.1(-13)$ & $5.5 \pm 0.2(+10)$ & $3.0 \pm 0.6(+20)$ & $3.7 \pm 0.1(+23)^{*}$ & $22 \pm 2$ & $45 \pm 4^{*}$ & $35 \pm 5^{\ddagger}$ & $53 \pm 2^{*}$ \\
\hline 125 U IL-3 & $13.8 \pm 1.0(-11)$ & $10.4 \pm 1.6(-21)$ & $4.0 \pm 0.8(-20)$ & $2.5 \pm 0.5(0)$ & $2.1 \pm 0.5(-30)$ & $7 \pm 1$ & $43 \pm 9 *$ & $37 \pm 4^{\ddagger}$ & $52 \pm 2^{*}$ \\
\hline
\end{tabular}

Mice were pretreated with $50 \mu \mathrm{g}$ endotoxin-depleted human lactoferrin i.v. $3 \mathrm{~h}$ later they were treated i.v. with control medium or various concentrations of IL-3. Mice were sacrificed $22 \mathrm{~h}$ later. Results for control diluent and 2,000 U IL-3 are averages of nine mice per group (in a total of three experiments) and results for 125-1,000 $\mathrm{U}$ are averages of six mice per group (two experiments). Numbers in parentheses designate the percent change $(\% \Delta)$ from control. ${ }^{*} P<0.005$ compared with control medium. ${ }^{\ddagger} P<0.05$ compared with control medium. 
Table V. Influence of Purified Recombinant Murine IL-3 In Vivo on the Numbers of Splenic Nucleated Cells, Hematopoietic Progenitor Cells, and the Cycling Status of Progenitor Cells in Mice Pretreated with Lactoferrin

\begin{tabular}{|c|c|c|c|c|c|c|c|c|c|}
\hline \multirow[b]{2}{*}{ Test material } & \multirow{2}{*}{$\begin{array}{l}\text { Nucleated cells } \\
\times 10^{-6} / \text { spleen }\end{array}$} & \multicolumn{4}{|c|}{ Colonies $\times 10^{-3} /$ spleen $(\% \Delta)$} & \multicolumn{4}{|c|}{ Percent cells in S-phase } \\
\hline & & CFU-GM & BFU-E-2 & BFU-E-1 & CFU-GEMM & CFU-GM & BFU-E-2 & BFU-E-1 & CFU-GEMM \\
\hline Control medium & $134 \pm 8$ & $3.7 \pm 0.7$ & $4.4 \pm 1.8$ & $3.5 \pm 0.4$ & $1.3 \pm 0.3$ & $16 \pm 1$ & $18 \pm 9$ & $-3 \pm 14$ & $-2 \pm 19$ \\
\hline 2,000 U IL-3 & $135 \pm 1(+1)$ & $5.7 \pm 0.9(+54)^{*}$ & $7.9 \pm 0.6(+80)^{*}$ & $4.6 \pm 0.4(+31)^{*}$ & $2.8 \pm 0.8(+115)^{*}$ & $56 \pm 0^{\ddagger}$ & $47 \pm 2^{\ddagger}$ & $32 \pm 1^{\ddagger}$ & $60 \pm 10^{\ddagger}$ \\
\hline 1,000 U IL-3 & $126 \pm 13(-6)$ & $3.4 \pm 0.1(-8)$ & $6.7 \pm 1.8(+52)$ & $3.9 \pm 1.0(+11)$ & $2.2 \pm 0.7(+69)$ & $46 \pm 10^{\ddagger}$ & $46 \pm 6^{\ddagger}$ & $38 \pm 5^{\ddagger}$ & $60 \pm 1^{\ddagger}$ \\
\hline 500 U IL-3 & $116 \pm 26(-13)$ & $3.1 \pm 0.8(-16)$ & $6.2 \pm 0.8(+41)$ & $5.1 \pm 0.9(+46)$ & $1.9 \pm 0.3(+46)$ & $33 \pm 1^{\ddagger}$ & $48 \pm 2^{\ddagger}$ & $43 \pm 4^{\ddagger}$ & $48 \pm 5^{\ddagger}$ \\
\hline $250 \mathrm{U}$ IL-3 & $160 \pm 21(+19)$ & $4.1 \pm 0.9(+11)$ & $7.1 \pm 1.5(+61)$ & $5.5 \pm 1.0(+57)$ & $1.7 \pm 0.3(+31)$ & $15 \pm 11$ & $40 \pm 4^{\ddagger}$ & $41 \pm 10^{\ddagger}$ & $23 \pm 13^{*}$ \\
\hline 125 U IL-3 & $145 \pm 4(+8)$ & $4.8 \pm 1.4(+30)$ & $6.4 \pm 0.1(+45)$ & $3.0 \pm 0.3(-14)$ & $0.8 \pm 0.1(-38)$ & $12 \pm 2$ & $16 \pm 10$ & $-15 \pm 8$ & $-14 \pm 4$ \\
\hline
\end{tabular}

Mice were pretreated with $50 \mu \mathrm{g}$ endotoxin-depleted human lactoferrin i.v. $3 \mathrm{~h}$ later they were treated with control medium or various concentrations of IL-3. Mice were sacrificed $22 \mathrm{~h}$ later. Results are the average of six mice (in a total of two experiments). Numbers in parentheses designate the percent $(\% \Delta)$ from control. ${ }^{*} P<0.05$ compared with control medium. ${ }^{\ddagger} P<0.005$ compared with control medium.

VII and VIII) and the marrow progenitors (Table VII) were more sensitive than the splenic progenitors (Table VIII) to the enhancing effects of CSF-1. These experiments (Tables VII and VIII) were performed differently from those reported in Table $\mathrm{VI}$ in that the growth factor was given to mice $3 \mathrm{~h}$, rather than $12 \mathrm{~h}$, after the LF inoculation. Under these conditions a significant increase in the numbers of bone marrow CFU-GM, BFUE-2, BFU-E-1, and CFU-GEMM was only detected in one of these three experiments using 20,000 U of CSF-1 (data not shown). There was no detectable effect of up to $10,000 \mathrm{U}$ of CSF-1 on marrow progenitor cell numbers and of up to 20,000 $U$ of CSF-1 on splenic progenitor cell numbers. No effect was detected on marrow or splenic total nucleated cellularity or on peripheral blood counts with up to 20,000 U CSF-1 (data not shown).

Effects of GM-CSF in vivo. The administration of 10,000 U GM-CSF i.v. to previously untreated mice, in two separate experiments, resulted after $24 \mathrm{~h}$ in significant increases $(P<0.05)$

Table VI. Influence of Purified Mouse CSF-1 In Vivo on Numbers of Femoral Nucleated Cells, Hematopoietic Progenitor Cells, and on Cycling Status of Progenitors in Mice Pretreated with Lactoferrin

\begin{tabular}{|c|c|c|c|c|c|c|c|c|c|}
\hline \multirow[b]{2}{*}{ Test material } & \multirow{2}{*}{$\begin{array}{l}\text { Nucleated cells } \\
\times 10^{-6} / \text { femur }\end{array}$} & \multicolumn{4}{|c|}{ Colonies $\times 10^{-3} /$ femur $(\% \Delta)$} & \multicolumn{4}{|c|}{ Percent of cells in S-phase } \\
\hline & & CFU-GM & BFU-E-2 & BFU-E-1 & CFU-GEMM & CFU-GM & BFU-E-2 & BFU-E-1 & CFU-GEMM \\
\hline \multicolumn{10}{|c|}{ Exp. $1 \mathrm{LF}, 12 \mathrm{~h}$ later test material, $3 \mathrm{~h}$ later sacrifice mice } \\
\hline $\begin{array}{l}\text { Control diluent } \\
\text { CSF-1 }\end{array}$ & $21.5 \pm 1.8$ & $35.2 \pm 2.4$ & $2.4 \pm 0.5$ & $2.8 \pm 0.2$ & $4.1 \pm 0.2$ & $12 \pm 3$ & $24 \pm 6$ & $28 \pm 6$ & $25 \pm 3$ \\
\hline$(20,000 \mathrm{U})$ & $16.8 \pm 1.6(-22)$ & $36.4 \pm 5.0(+3)$ & $2.8 \pm 0.3(+17)$ & $2.3 \pm 0.3(-18)$ & $5.3 \pm 0.6(+29)^{*}$ & $68 \pm 3^{*}$ & $81 \pm 1^{*}$ & $47 \pm 5^{*}$ & $57 \pm 6^{*}$ \\
\hline \multicolumn{10}{|c|}{ Exp. $2 \mathrm{LF}, 12 \mathrm{~h}$ later test material, $12 \mathrm{~h}$ later sacrifice mice } \\
\hline $\begin{array}{l}\text { Control diluent } \\
\text { CSF-1 }\end{array}$ & $20.2 \pm 1.4$ & $10.9 \pm 1.5$ & $4.3 \pm 0.8$ & $2.5 \pm 0.1$ & $2.0 \pm 0.2$ & $11 \pm 3$ & $4 \pm 2$ & $3 \pm 3$ & $4 \pm 3$ \\
\hline$(20,000 \mathrm{U})$ & $19.5 \pm 0.5(-3)$ & $16.3 \pm 2.9(+50)^{*}$ & $4.3 \pm 0.6(0)$ & $3.8 \pm 0.3(+52)^{*}$ & $4.0 \pm 0.2(+100)^{*}$ & $45 \pm 10^{*}$ & $50 \pm 7^{*}$ & $47 \pm 3^{*}$ & $61 \pm 7^{*}$ \\
\hline \multicolumn{10}{|c|}{ Exp. $3 \mathrm{LF}, 12 \mathrm{~h}$ later test material, $24 \mathrm{~h}$ later sacrifice mice } \\
\hline $\begin{array}{l}\text { Control diluent } \\
\text { CSF-1 }\end{array}$ & $16.3 \pm 0.9$ & $13.9 \pm 1.2$ & $5.5 \pm 0.6$ & $2.5 \pm 0.1$ & $3.3 \pm 0.1$ & $23 \pm 5$ & $15 \pm 5$ & $5 \pm 5$ & $1 \pm 3$ \\
\hline$(20,000 \mathrm{U})$ & $14.4 \pm 1.0(-12)$ & $18.5 \pm 1.5(+33)^{*}$ & $7.5 \pm 0.7(+36)^{*}$ & $3.3 \pm 0.4(+32)^{*}$ & $4.7 \pm 0.5(+42)^{*}$ & $67 \pm 3^{*}$ & $62 \pm 5^{*}$ & $49 \pm 7^{*}$ & $56 \pm 3^{*}$ \\
\hline \multicolumn{10}{|c|}{ Exp. $4 \mathrm{LF}, 12 \mathrm{~h}$ later test material, $48 \mathrm{~h}$ later sacrifice mice } \\
\hline $\begin{array}{l}\text { Control diluent } \\
\text { CSF-1 }\end{array}$ & $20.7 \pm 1.2$ & $12.7 \pm 0.5$ & $3.0 \pm 0.3$ & $4.3 \pm 0.6$ & $0.9 \pm 0.3$ & $20 \pm 6$ & $31 \pm 5$ & $6 \pm 7$ & $12 \pm 7$ \\
\hline$(20,000 \mathrm{U})$ & $20.0 \pm 1.0(-3)$ & $15.8 \pm 1.2(+24)$ & $4.2 \pm 0.7(+40)$ & $6.0 \pm 1.0(+40)$ & $1.1 \pm 0.3(+22)$ & $34 \pm 8$ & $38 \pm 4$ & $25 \pm 19$ & $20 \pm 10$ \\
\hline \multicolumn{10}{|c|}{ Exp. $5 \mathrm{LF}, 12 \mathrm{~h}$ later test material, $12 \mathrm{~h}$ later $\mathrm{LF}(3 \mathrm{~h})$ test material $(24 \mathrm{~h})$, sacrifice mice } \\
\hline $\begin{array}{l}\text { Control diluent } \\
\text { CSF-1 }\end{array}$ & $19.7 \pm 0.7$ & $9.8 \pm 0.9$ & $7.5 \pm 0.2$ & $2.1 \pm 0.2$ & $1.4 \pm 0.4$ & $10 \pm 2$ & $17 \pm 2$ & $6 \pm 6$ & $3 \pm 3$ \\
\hline$(20,000 \mathrm{U})$ & $18.5 \pm 1.0(-6)$ & $18.4 \pm 1.5(+88)^{*}$ & $6.5 \pm 1.4(-13)$ & $3.1 \pm 0.2(+48)^{*}$ & $3.1 \pm 0.2(+121)^{*}$ & $61 \pm 5^{4}$ & $21 \pm 2$ & $61 \pm 11^{\circ}$ & $71 \pm 11^{*}$ \\
\hline
\end{tabular}

Mice were pretreated with $50 \mu \mathrm{g}$ endotoxin-depleted human lactoferrin i.v. and then treated i.v. with control diluent or CSF-1 as described. Each experiment is the average of three mice per group. Numbers in parentheses designate the percent $(\% \Delta)$ from control. * Significant percent change $(\% \Delta)$ from mice injected with control diluent, $P<0.05$. None of the decreases were significant. 
Table VII. Influence of Purified Mouse CSF-1 on the Cycling Status of Bone Marrow Hematopoietic Progenitor Cells In Vivo after Mice have been Pretreated with Purified Human Lactoferrin

\begin{tabular}{llccc}
\hline & \multicolumn{4}{l}{ Percent of cells in S-phase } \\
\cline { 2 - 5 } Test material & CFU-GM & BFU-E-2 & BFU-E-1 & CFU-GEMM \\
\hline Control diluent & $21 \pm 4$ & $13 \pm 4$ & $2 \pm 4$ & $0 \pm 0.3$ \\
$20,000 \mathrm{U}$ & $65 \pm 3^{*}$ & $61 \pm 4^{*}$ & $46 \pm 5^{*}$ & $58 \pm 3^{*}$ \\
$10,000 \mathrm{U}$ & $53 \pm 1^{*}$ & $39 \pm 1^{*}$ & $25 \pm 0^{*}$ & $25 \pm 14^{\ddagger}$ \\
$5,000 \mathrm{U}$ & $31 \pm 4^{\ddagger}$ & $13 \pm 15$ & $13 \pm 4$ & $2 \pm 8$ \\
$2,500 \mathrm{U}$ & $29 \pm 1^{\ddagger}$ & $3 \pm 13$ & $10 \pm 1$ & $8 \pm 5$ \\
$1,250 \mathrm{U}$ & $20 \pm 1$ & $6 \pm 13$ & $16 \pm 2$ & $-0.5 \pm 18$
\end{tabular}

Mice were pretreated with $50 \mu \mathrm{g}$ endotoxin-depleted human lactoferrin i.v. $3 \mathrm{~h}$ later they were treated i.v. with control medium or various concentrations of CSF-1. Mice were sacrificed $22 \mathrm{~h}$ later. Results for control diluent and 20,000 U CSF-1 are averages of nine mice per group (in a total of three experiments) and results for 1,250-10,000 U are averages of six mice per group (two experiments).

* $P<0.005$ compared with control medium.

${ }^{\ddagger} P<0.05$ compared with control medium.

in the cycling status of marrow CFU-GM $(54 \pm 1 \%$ and $57 \pm 3 \%$ in S-phase) when compared with the cycling status of CFU-GM (34 $\pm 4 \%$ and $44 \pm 3 \%$ in S-phase) in mice given control diluent. No significant effect was detected on the cycling status of BFUE-2 in these mice with $18 \pm 5 \%$ and $12 \pm 5 \%$ of cells in S-phase in mice given GM-CSF compared with $13 \pm 4 \%$ and $7 \pm 2 \%$ of cells in S-phase in mice receiving control diluent. In these mice, GMCSF had no effect on the total nucleated cellularity or on the absolute number of CFU-GM and BFU-E-2 in the marrow. Because the effects of GM-CSF given to previously untreated mice were only minimal, and based on the experience using LF-pretreated mice as a more sensitive assay to detect the stimulating effects in vivo of IL-3 and CSF-1, the effects of varying concentrations of GM-CSF were evaluated on marrow and splenic nucleated cellularity, numbers of progenitors per organ and on the

Table VIII. Influence of Purified Mouse CSF-1 on the Cycling Status of Splenic Hematopoietic Progenitor Cells In Vivo after Mice Have Been Pretreated with Purified Human Lactoferrin

\begin{tabular}{lcccc}
\hline & \multicolumn{3}{l}{ Percent of cells in S-phase } & \\
\cline { 2 - 5 } Test material & CFU-GM & BFU-E-2 & BFU-E-1 & CFU-GEMM \\
\hline Control medium & $6 \pm 6$ & $7 \pm 4$ & $-11 \pm 16$ & $4 \pm 8$ \\
$20,000 \mathrm{U}$ & $51 \pm 5^{*}$ & $35 \pm 10^{*}$ & $42 \pm 5^{*}$ & $41 \pm 9^{*}$ \\
$10,000 \mathrm{U}$ & $37 \pm 3^{*}$ & $12 \pm 10$ & $16 \pm 9$ & $45 \pm 10^{*}$ \\
$5,000 \mathrm{U}$ & $35 \pm 4^{*}$ & $4 \pm 1$ & $-4 \pm 10$ & $4 \pm 16$ \\
$2,500 \mathrm{U}$ & $7 \pm 3$ & $6 \pm 4$ & $12 \pm 4$ & $8 \pm 2$ \\
$1,250 \mathrm{U}$ & $16 \pm 1$ & $0 \pm 4$ & & \\
& & & & \\
\hline
\end{tabular}

Mice were pretreated with $50 \mu \mathrm{g}$ endotoxin-depleted human lactoferrin i.v. $3 \mathrm{~h}$ later they were treated i.v. with control medium or various concentrations of CSF- 1 . Mice were sacrificed $22 \mathrm{~h}$ later. Results are the averages of six mice (in a total of two experiments).

* $P<0.005$ compared with control medium, other numbers are not significantly different from control $(P>0.05)$.
Table IX. Influence of Pure Recombinant Murine GM-CSF In Vivo on Cycling Status of Femoral Hematopoietic Progenitor Cells in Mice Pretreated with Human Lactoferrin

\begin{tabular}{llccc}
\hline \multicolumn{5}{l}{ Percent of cells in S-phase } \\
\cline { 2 - 5 } Test material & CFU-GM & BFU-E-2 & BFU-E-1 & CFU-GEMM \\
\hline Control diluent & $23 \pm 2$ & $16 \pm 5$ & $8 \pm 7$ & $0.3 \pm 10$ \\
20,000 U GM-CSF & $59 \pm 7^{*}$ & $24 \pm 7$ & $0.5 \pm 12$ & $62 \pm 8^{*}$ \\
10,000 U GM-CSF & $64 \pm 3^{*}$ & $8 \pm 5$ & $2 \pm 8$ & $45 \pm 4^{*}$ \\
5,000 U GM-CSF & $47 \pm 5^{*}$ & $16 \pm 7$ & $2 \pm 9$ & $31 \pm 10^{*}$ \\
2,500 U GM-CSF & $47 \pm 4^{*}$ & $12 \pm 5$ & $1 \pm 4$ & $1 \pm 4$ \\
1,250 U GM-CSF & $24 \pm 3$ & $9 \pm 6$ & $0.2 \pm 5$ & $0.2 \pm 3$ \\
& & & & \\
\hline
\end{tabular}

Mice were pretreated with $50 \mu \mathrm{g}$ endotoxin-depleted human lactoferrin i.v., given control diluent or GM-CSF i.v. $3 \mathrm{~h}$ later, and sacrificed $24 \mathrm{~h}$ later. Results are the average of 6-8 mice/group (from a total of two experiments).

* Significant change from mice given control diluent, $P<0.001$.

Other changes are not significant, $P>0.05$.

cycling status of progenitors in these organs in mice pretreated with LF. The results on the cycling status of marrow and splenic progenitors are shown respectively in Tables IX and X. GMCSF increased the percent of marrow and splenic CFU-GM and CFU-GEMM in S-phase, but had no significant effect on the cycling status of BFU-E-2 and BFU-E-1. The cycling status of CFU-GM was more sensitive to the enhancing effects of GMCSF than was the cycling status of CFU-GEMM and at least for CFU-GEMM, the marrow appeared to be a more sensitive organ than the spleen to these effects. Not shown is that concentrations of 1,250-20,000 U of GM-CSF had no significant effect on the nucleated cellularity, on numbers of CFU-GM, BFU-E-2, BFUE, or CFU-GEMM per femur or spleen, or on peripheral blood counts.

Comparative effects of IL-3, CSF-1, and bacterial lipopolysaccharide (LPS) in vivo in mice pretreated with $L F$. No contamination of endotoxin could be detected in the CSF samples

Table X. Influence of Pure Recombinant Murine GM-CSF In Vivo on Cycling Status of Splenic Hematopoietic Progenitor Cells in Mice Pretreated with Human Lactoferrin

\begin{tabular}{llrrr}
\hline \multicolumn{5}{l}{ Percent of cells in S-phase } \\
\cline { 2 - 5 } Test material & CFU-GM & BFU-E-2 & BFU-E-1 & CFU-GEMM \\
\hline Control diluent & $15 \pm 1$ & $6 \pm 2$ & $3 \pm 6$ & $4 \pm 1$ \\
20,000 U GM-CSF & $53 \pm 3^{*}$ & $10 \pm 7$ & $13 \pm 5$ & $40 \pm 12^{*}$ \\
10,000 U GM-CSF & $46 \pm 10^{*}$ & $1 \pm 5$ & $19 \pm 5$ & $38 \pm 9^{*}$ \\
5,000 U GM-CSF & $51 \pm 6^{*}$ & $-2 \pm 8$ & $9 \pm 9$ & $4 \pm 1$ \\
2,500 U GM-CSF & $37 \pm 5^{*}$ & $-4 \pm 7$ & $-5 \pm 0$ & $-6 \pm 6$ \\
1,250 U GM-CSF & $18 \pm 2$ & $9 \pm 1$ & $-12 \pm 3$ & $-12 \pm 3$ \\
& & & & \\
\hline
\end{tabular}

Mice were pretreated with $50 \mu \mathrm{g}$ endotoxin-depleted iron-saturated human lactoferrin i.v., given control diluent or GM-CSF i.v. $3 \mathrm{~h}$ later and sacrificed $24 \mathrm{~h}$ later. Results are for three mice per group (one experiment).

* Significant change from mice given control diluent, $P<0.005$.

Other changes are not significant, $P>0.05$. 
Table XI. Comparative Influences of Purified Murine CSF-1, Purified Recombinant

Murine IL-3, and E. Coli Lipopolysaccharide In Vivo on Numbers of Femoral Nucleated Cells, Hematopoietic Progenitor Cells, and on Cycling Status of the Progenitors in Mice Pretreated with Lactoferrin

\begin{tabular}{|c|c|c|c|c|c|c|c|c|c|}
\hline \multirow[b]{2}{*}{ Test material } & \multirow{2}{*}{$\begin{array}{l}\text { Nucleated cells } \\
\times 10^{-6} / \text { femur }\end{array}$} & \multicolumn{4}{|c|}{ Colonies $\times 10^{-3} /$ femur $(\% \Delta)$} & \multicolumn{4}{|c|}{ Percent of cells in S-phase } \\
\hline & & CFU-GM & BFU-E-2 & BFU-E-1 & CFU-GEMM & CFU-GM & BFU-E-2 & BFU-E-1 & CFU-GEMM \\
\hline Control medium & $17 \pm 1$ & $15 \pm 0.4$ & $2.0 \pm 0.2$ & $3.5 \pm 0.1$ & $3.5 \pm 0.5$ & $6 \pm 2$ & $-5 \pm 5$ & $29 \pm 2$ & $32 \pm 6$ \\
\hline 20,000 U CSF-1 & $19 \pm 3(+12)$ & $27 \pm 3(+80)^{*}$ & $4.4 \pm 0.1(+120)^{*}$ & $3.3 \pm 0.5(-6)$ & $4.7 \pm 0.3(+34)^{*}$ & $69 \pm 4^{*}$ & $62 \pm 2^{*}$ & $46 \pm 8^{*}$ & $50 \pm 3^{*}$ \\
\hline 500 U IL-3 & $17 \pm 1(0)$ & $14 \pm 2(-7)$ & $3.0 \pm 0.4(+50)^{*}$ & $3.2 \pm 0.3(-9)$ & $4.7 \pm 0.2(+34)^{*}$ & $49 \pm 1^{*}$ & $49 \pm 13^{*}$ & $41 \pm 6^{*}$ & $68 \pm 9^{*}$ \\
\hline 100 ng LPS & $14 \pm 1(-18)$ & $14 \pm 1(-7)$ & $2.4 \pm 0.1(+20)$ & $3.4 \pm 0.5(-3)$ & $2.6 \pm 0.6(-26)$ & $21 \pm 2^{*}$ & $0 \pm 6$ & $15 \pm 9$ & $23 \pm 13$ \\
\hline 10 ng LPS & $15 \pm 2(-12)$ & $14 \pm 2(-7)$ & $2.3 \pm 0.3(+15)$ & $3.0 \pm 1.0(-14)$ & $2.9 \pm 0.9(-17)$ & $18 \pm 1^{*}$ & $3 \pm 3$ & $11 \pm 11$ & $0 \pm 0^{\ddagger}$ \\
\hline 1 ng LPS & $14 \pm 1(-18)$ & $12 \pm 2(-20)$ & $1.9 \pm 0.4(-5)$ & $2.5 \pm 0.3(-29)^{\ddagger}$ & $2.4 \pm 0.1(-31)^{\ddagger}$ & $8 \pm 6$ & $0 \pm 1$ & $16 \pm 9$ & $2 \pm 19^{\ddagger}$ \\
\hline $0.1 \mathrm{ng}$ LPS & $19 \pm 1(+12)$ & $14 \pm 1(-7)$ & $2.2 \pm 0.1(+10)$ & $3.3 \pm 0.1(-6)$ & $2.7 \pm 0.4(-23)$ & $1 \pm 2$ & $-9 \pm 9$ & $14 \pm 6$ & $8 \pm 18$ \\
\hline
\end{tabular}

Mice were given $50 \mu \mathrm{g}$ endotoxin-depleted lactoferrin i.v. at time $0.12 \mathrm{~h}$ later three mice per group were given test material i.v. Mice were sacrificed $24 \mathrm{~h}$ after test material. Numbers in parentheses designate the percent $(\% \Delta)$ from control. ${ }^{*}$ Significant percent increase when compared with control medium, $P<0.05$. 'Significant percent decrease when compared with control medium, $P<0.05$.

using the Limulus lysate assay $(<0.1 \mathrm{ng} / \mathrm{sample})$ and it was therefore unlikely that the effects of IL-3, CSF-1, and GM-CSF noted in vivo were due to contaminating endotoxin. However, the effects of varying concentrations of $E$. coli LPS were assessed in mice pretreated with $50 \mu \mathrm{g} \mathrm{LF}$. The results comparing the effects of 20,000 U CSF-1, 500 U IL-3, and 0.1-100 ng LPS on marrow and splenic hematopoiesis are shown respectively in Tables XI and XII. The stimulating effects of CSF-1 and IL-3 were similar to the effects noted above, but these stimulating actions were not mimicked by $0.1-100 \mathrm{ng}$ LPS, except for a few isolated and very slight effects.

\section{Discussion}

When administered to mice, recombinant IL-3, natural CSF-1, and recombinant GM-CSF have a stimulating effect on marrow and splenic hematopoietic progenitor cells that is consistent with known direct and indirect effects of these molecules on the progenitor cells in vitro. The effects in vivo are most apparent when myelopoiesis in the test mice is first suppressed by administration of purified fully iron-saturated human LF. It has also been shown elsewhere that marrow and spleen progenitor cells in mice 6-7 d after a sublethal dosage of cyclosphamide are more sensitive than these cells in untreated mice to the in vivo cell cycle-stimulating effects of natural CSF-1 (68) and natural IL-3 (69). Differences, which may be more quantitative than qualitative, were noted in the present report between the actions of these preparations of CSF in vivo. In contrast to purified natural murine IL-3, which in our experience is a good stimulator of CFU-GM colony formation in vitro (69), our preparation of recombinant murine IL-3 was not a potent stimulator of CFU-GM colonies in vitro. Nevertheless, the recombinant IL-3 increased the cycling status and absolute numbers of marrow and splenic hematopoietic progenitor cells, and dose response curves with varying concentrations of IL-3 demonstrated that the BFU-E and CFUGEMM progenitor cell compartments were more sensitive to the effects of IL-3 than was the CFU-GM compartment. This correlated well with the actions of the preparation in vitro. In contrast, CSF-1, while manifesting effects on these same progenitor cells, appeared to be a more effective stimulator at lower concentrations for CFU-GM than for BFU-E and CFU-GEMM. GM-CSF was more effective in stimulating CFU-GM than CFUGEMM, and had no influence on the BFU-E compartments. Of potential physiological relevance is that the enhancement of

Table XII. Comparative Influences of Purified Murine CSF-1, Purified Recombinant Murine IL-3, and E. Coli Lipopolysaccharide In Vivo on Numbers of Splenic Nucleated Cells, Hematopoietic Progenitor Cells, and on Cycling Status of the Progenitors in Mice Pretreated with Lactoferrin

\begin{tabular}{|c|c|c|c|c|c|c|c|c|c|}
\hline \multirow[b]{2}{*}{ Test material } & \multirow{2}{*}{$\begin{array}{l}\text { Nucleated cells } \\
\times 10^{-6} / \text { spleen }\end{array}$} & \multicolumn{4}{|c|}{ Colonies $\times 10^{-3} /$ spleen $(\% \Delta)$} & \multicolumn{4}{|c|}{ Percent of cells in S-phase } \\
\hline & & CFU-GM & BFU-E-2 & BFU-E-1 & CFU-GEMM & CFU-GM & BFU-E-2 & BFU-E-1 & CFU-GEMM \\
\hline Control medium & $102 \pm 9$ & $38 \pm 3$ & $27 \pm 6$ & $44 \pm 6$ & $14 \pm 0.2$ & $4 \pm 4$ & $3 \pm 3$ & $13 \pm 17$ & $8 \pm 1$ \\
\hline 20,000 U CSF-1 & $125 \pm 15(+23)$ & $112 \pm 31(+195)^{*}$ & $90 \pm 22(+233)^{*}$ & $119 \pm 7(+170)^{*}$ & $44 \pm 16(+214)^{*}$ & $58 \pm 2^{*}$ & $58 \pm 6^{*}$ & $44 \pm 11^{*}$ & $70 \pm 1^{*}$ \\
\hline 500 U IL-3 & $77 \pm 12(-25)$ & $33 \pm 1(-13)$ & $38 \pm 3(+41)^{*}$ & $59 \pm 5(+34)^{*}$ & $15 \pm 3(+7)$ & $58 \pm 4^{*}$ & $58 \pm 5$ & $54 \pm 4^{*}$ & $71 \pm 8^{*}$ \\
\hline $100 \mathrm{ng}$ LPS & $109 \pm 12(+7)$ & $32 \pm 1(-16)$ & $33 \pm 1(+22)$ & $47 \pm 5(+7)$ & $11 \pm 3(-21)$ & $4 \pm 8$ & $3 \pm 0$ & $9 \pm 3$ & $13 \pm 13$ \\
\hline 10 ng LPS & $135 \pm 15(+32)^{*}$ & $59 \pm 19(+55)$ & $41 \pm 10(+52)$ & $53 \pm 6(+20)$ & $19 \pm 4(+36)$ & $7 \pm 1$ & $2 \pm 2$ & $3 \pm 0$ & $0 \pm 8$ \\
\hline $1 \mathrm{ng}$ LPS & $125 \pm 15(+23)$ & $40 \pm 12(+5)$ & $53 \pm 14(+96)^{*}$ & $52 \pm 17(+18)$ & $15 \pm 2(+7)$ & $10 \pm 2$ & $0 \pm 6$ & $1 \pm 1$ & $0 \pm 1$ \\
\hline $0.1 \mathrm{ng}$ LPS & $86 \pm 4(-16)$ & $23 \pm 1(-39)^{\ddagger}$ & $19 \pm 1(-30)$ & $35 \pm 2(-20)$ & $9 \pm 1(-36)^{\ddagger}$ & $8 \pm 4$ & $4 \pm 13$ & $2 \pm 2$ & $-2 \pm 20$ \\
\hline
\end{tabular}

Mice were given $50 \mu \mathrm{g}$ endotoxin-depleted lactoferrin i.v. at time $0.12 \mathrm{~h}$ later three mice per group were given test material i.v. Mice were sacrificed $24 \mathrm{~h}$ after test material. Numbers in parentheses designate the percent $(\% \Delta)$ from control. * Significant percent increase when compared with control medium, $P<0.05$. ${ }^{\ddagger}$ Significant percent decrease when compared with control medium, $P<0.05$. 
the percent of progenitors in the S-phase of the cell cycle was a more sensitive parameter for assessing the actions of the CSF preparations in vivo than were the effects of these preparations on increasing the absolute numbers of progenitors per marrow or spleen. IL-3 and CSF-1, at high concentrations, increased the numbers of hematopoietic progenitors, but the effects of CSF-1 on this parameter were variable. Moreover, GM-CSF did not enhance the absolute numbers of progenitor cells per organ at any of the concentrations tested. Also, marrow progenitors were more sensitive than spleen progenitors to the stimulating effects of the CSF preparations in vivo.

Our reasons for using LF to pretreat the mice were two-fold. First, we reasoned that it would be easier to detect effects of an exogenously added preparation of CSF if myelopoiesis in the mice was first suppressed. Human LF, when administered to mice, decreases partially the absolute numbers of CFU-GM, BFU-E, and CFU-GEMM and completely decreases or substantially slows the cycling status of these progenitors in vivo $(55,61,62)$. It is believed that the myelosuppressive effects of LF in vivo may result indirectly from decreased release of growth factors. LF decreases the release from monocytes and macrophages in vitro of growth factors that are necessary for the proliferation and differentiation of granulocytes and macrophages (55-60). Serum obtained from mice receiving LF contains less CSF for granulocyte and macrophage colony formation in vitro and organs taken from mice pretreated with LF release less of these factors in vitro (55). It is not yet known if LF directly or indirectly decreases the release of IL-3, or other factors with multi-activities in vitro or in vivo. Our second reason for using LF is that pure preparations of CSF are known to induce the release from monocytes and macrophages in vitro of suppressor molecules for hematopoietic progenitors, such as prostaglandin E (45), acidic isoferritins (41), interferon-alpha $(44,46)$, and tumor necrosis factor (46). Thus the possibility existed that stimulating effects-of CSF in vivo might be masked by suppressor molecules induced by the CSF. Since LF suppresses release of PGE (45) and acidic isoferritins (41) from monocytes and macrophages in vitro, it was possible that LF could decrease the CSF-induced release of suppressor molecules in addition to decreasing the endogenous production/release of growth factors.

Endotoxins cause a number of hematopoietic effects in vivo, including increased release of colony-stimulating activities, and enhanced myelopoiesis due to increased blood cell production and increased release of granulocytes from the marrow granulocyte reserve $(56,63,70)$. For this reason we carefully controlled for the potential effects of contaminating endotoxin. Our preparations of CSF did not contain endotoxin, at least within the sensitivity of the Limulus lysate test, and the effects of IL-3, CSF-1, and GM-CSF in vivo were not mimicked by concentrations of 0.1-100 ng $E$. coli LPS. Full dose response curves were done with LPS because LPS can have both stimulating and suppressing activities that can be related to the concentrations of LPS used. Further evidence against CSF effects being due to contamination of endotoxin is that the preparations of CSF had no effect on the circulating levels of granulocytes, monocytes, or lymphocytes within 3 to $48 \mathrm{~h}$ after administration of the CSF to previously untreated mice (data not shown). Of interest to the relative inactivity of LPS in these mice is that they were pretreated with LF. LF counteracts the release of CSF induced by LPS in vitro, but this depends on the relative concentrations of LPS to LF present in the culture $(55,56)$. Other investigators have used $\mathrm{C} 3 \mathrm{H} / \mathrm{HEJ}$ mice as a model to rule out the possibility of recombinant IL-3 effects being due to endotoxin (51-53), however $\mathrm{C} 3 \mathrm{H} / \mathrm{HEJ}$ mice are less sensitive, but not resistant, to the effects of LPS (56).

Our studies do not allow us to conclude whether the effects of IL-3, CSF-1, and GM-CSF in vivo are direct ones on the hematopoietic progenitors in the marrow and spleen, whether these effects are mediated through an action on accessory cells present in the blood, marrow, or spleen, or if the actions are both direct and indirect. It is possible that at least some of the effects of IL-3 noted in vivo are direct ones on the progenitors. CSF-1 stimulates macrophage progenitors directly (71), and in an unseparated population of marrow cells it stimulates colonies of granulocytes and granulocytes plus macrophages, as well as macrophages (Table II), but there is no evidence that CSF-1 can act as a BPA or multi-CSF in vitro (Table I). GM-CSF, in addition to its direct effect on CFU-GM in vitro (71), has a proliferative effect on CFU-GEMM and BFU-E (72) and there are reports that GM-CSF may be a multi-CSF (73). However, this latter report was based on experiments using enriched but not pure populations of progenitors, and it is still possible that these effects were indirect. Using an unseparated population of marrow cells, we could not detect BPA or multi-CSF activity in our preparation of recombinant GM-CSF at concentrations up to those stimulating plateau levels of granulocyte and macrophage colony formation. These results are consistent with recent reports from two other groups using recombinant murine GM-CSF (74, 75). There are reports of CSF preparations stimulating the release of other types of CSF from cells in vitro $(46-48)$, and it is probable that at least some of the effects in vivo of IL-3, CSF-1, and GMCSF are mediated through the induced release of other growth factors for hematopoietic stem and progenitor cells.

Our studies were designed to study only the short term effects of relatively low concentrations of IL-3, CSF-1, and GM-CSF in vivo. During the time periods evaluated (up to $48 \mathrm{~h}$ ) and under the conditions of our experiments, we did not detect any effect on total marrow or splenic nucleated cells or on circulating levels or differentials of blood cells. The inability to detect changes in the mature myeloid blood cell compartments may be a manifestation of the short period of evaluation, the need for higher concentrations of factors, multiple factors, and/or multiple additions of one or more factors, including those that may be more involved in differentiation as compared with proliferation.

\section{Acknowledgments}

We wish to thank Stephanie Moore and Shirley Duke for excellent secretarial assistance.

These studies were supported by Public Health Service grants CA36464 and CA-36740 (Dr. Broxmeyer) and CA-15237 (Dr. Shadduck) from the National Cancer Institute. Dr. Williams was supported by $\mathrm{Na}$ tional Institutes of Health training program IT 32 AM-07519.

\section{References}

1. Broxmeyer, H. E. 1983. Colony assays of hematopoietic progenitor cells and correlations to clinical situations. CRC Crit. Rev. Oncol. Hematol. 1:227-257.

2. Metcalf, D. 1985. The granulocyte-macrophage colony stimulating factors. Science (Wash. DC). 229:16-22.

3. Ihle, J. N., J. Keller, L. Henderson, F. Klein, and E. Palaszynski. 1982. Procedures for the purification of interleukin 3 to homogeneity. J. Immunol. 129:2431-2436.

4. Clark-Lewis, I., S. B. H. Kent, and J. W. Schrader. 1984. Purifi- 
cation to apparent homogeneity of a factor stimulating the growth of multiple lineages of hemopoietic cells. J. Biol. Chem. 259:7488-7494.

5. Prestidge, R. L., J. D. Watson, D. L. Urdal, D. Mochizuki, P. Conlon, and S. Gillis. 1984. Biochemical comparison of murine colonystimulating factors secreted by a $\mathrm{T}$ cell lymphoma and a myelomonocytic leukemia. J. Immunol. 133:293-298.

6. Cutler, R. L., D. Metcalf, N. A. Nicola, and G. R. Johnson. 1985. Purification of a multipotential colony stimulating factor from pokeweed mitogen-stimulated mouse spleen cell conditioned medium. J. Biol. Chem. 260:6579-6587.

7. Welte, K., E. Platzer, L. Lu, J. Gabrilove, E. Levi, R. Mertelsmann, and M. A. S. Moore. 1985. Purification and biochemical characterization of human pluripotent hematopoietic colony stimulating factor. Proc. Natl. Acad. Sci. USA. 82:1526-1530.

8. Gabrilove, J., K. Welte, P. Harris, E. Platzer, L. Lu, E. Levi, R. Mertelsmann, and M. A. S. Moore. 1986. Pluripoietin $\alpha$ : a second human hematopoietic colony-stimulating factor produced by the human bladder carcinoma cell line 5637. Proc. Natl. Acad. Sci. USA. 83:2478-2482.

9. Stanley, E. R., and P. M. Heard. 1977. Factors regulating macrophage production and growth: purification and some properties of the colony stimulating factor from medium conditioned by mouse $\mathrm{L}$ cells. J. Biol. Chem. 252:4305-4312.

10. Waheed, A., and R. K. Shadduck. 1979. Purification and properties of L cell-derived colony stimulating factor. J. Lab. Clin. Med. 94: 180-194.

11. Waheed, A., and R. K. Shadduck. 1982. Purification of colonystimulating factor by affinity chromatography. Blood. 60:238-244.

12. Burgess, A. W., D. Metcalf, I. J. Kozka, R. J. Simpson, G. Vairo, J. A. Hamilton, and E. C. Nice. 1985. Purification of two forms of colonystimulating factor from mouse L-cell-conditioned medium. J. Biol. Chem. 260:16004-16011.

13. Burgess, A. W., J. Camakaris, and D. Metcalf. 1977. Purification and properties of colony-stimulating factor from mouse lung conditioned medium. J. Biol. Chem. 252:1998-2003.

14. Nicola, N. A., D. Metcalf, M. Matsumoto, and G. R. Johnson. 1983. Purification of a factor inducing differentiation in murine myelomonocytic leukemia cells: identification as granulocyte colony-stimulating factor (G-CSF). J. Biol. Chem. 258:9017-9023.

15. Fung, M. C., A. J. Hapel, S. Ymer, D. R. Cohen, R. M. Johnson, H. D. Campbell, and I. G. Young. 1984. Molecular cloning of cDNA for murine interleukin-3. Nature (Lond.). 307:233-237.

16. T. Yokota, F. Lee, D. Rennick, C. Hall, N. Arai, T. Mosmann, G. Nabel, H. Cantor, and K.-I. Arai. 1984. Isolation and characterization of a mouse cDNA clone that expresses mast-cell growth-factor activity in monkey cells. Proc. Natl. Acad. Sci. USA. 81:1070-1074.

17. Miyatake, S., T. Yokota, F. Lee, and K.-I. Arai. 1985. Structure of the chromosomal gene for murine interleukin-3. Proc. Natl. Acad. Sci. USA. 82:316-320.

18. Campbell, H. D., S. Ymer, M-C. Fung, and I. G. Young. 1985. Cloning and nucleotide sequence of the murine interleukin-3 gene. Eur. J. Biochem. 150:297-304.

19. Kawasaki, E. S., M. B. Ladner, A. M. Wang, J. Van Arsdell, M. K. Warren, M. Y. Coyne, V. L. Schweickart, M.-T. Lee, K. J. Wilson, A. Boosman, E. R. Stanley, P. Ralph, and D. F. Mark. 1985. Molecular cloning of a complementary DNA encoding human macrophage specific colony-stimulating factor (CSF-1). Science (Wash. DC). 230:291-296.

20. Gough, N. M., J. Gough, D. Metcalf, A. Kelso, D. Grail, N. A. Nicola, A. W. Burgess, and A. R. Dunn. 1984. Molecular cloning of cDNA encoding a murine haematopoietic growth regulator, granulocytemacrophage colony stimulating factor. Nature (Lond.). 309:763-767.

21. Lee, F., T. Yokota, T. Otsuka, L. Gemmell, N. Larson, J. Luh, K.-I. Arai, and D. Rennick. 1985. Isolation of cDNA for a human granulocyte-macrophage colony stimulating factor by functional expression in mammalian cells. Proc. Natl. Acad. Sci. USA. 82:4360-4364.

22. Wong, G. C., J. S. Witek, P. A. Temple, K. M. Wilkens, A. C. Leary, D. P. Luxenberg, S. S. Jones, E. L. Brown, R. M. Kay, E. C. Orr, C. Shoemaker, D. W. Golde, R. J. Kaufman, R. M. Hewick, E. A. Wang, and S. C. Clark. 1985. Human GM-CSF: Molecular cloning of the com- plementary DNA and purification of the natural and recombinant proteins. Science (Wash. DC). 228:810-815.

23. Cantrell, M. A., D. Anderson, D. P. Cerretti, V. Price, K. Mckereghan, R. J. Tushinski, D. Y. Mochizuki, A. Larsen, K. Grabstein, S. Gillis, and D. Cosman. 1985. Cloning, sequence, and expression of a human granulocyte-macrophage colony-stimulating factor. Proc. Natl. Acad. Sci. USA. 82:6250-6254.

24. Nagata, S., M. Tsuchiya, S. Asano, O. Yamamoto, Y. Hirata, N. Kubota, M. Oheda, H. Nomura, and T. Yamazaki. 1986. The chromosomal gene structure and two mRNAs for human granulocyte colonystimulating factor. EMBO (Eur. Mol. Biol. Organ.) J. 5:575-581.

25. Souza, L. M., T. C. Boone, J. Gabrilove, P. H. Lai, K. M. Zsebo, D. C. Murdock, V. R. Chazen, J. Bruszewski, H. Lu, K. C. Chen, J. Barendt, E. Platzer, M. A. S. Moore, R. Mertelsman, and K. Welte. 1986. Recombinant human granulocyte colony-stimulating factor: effects on normal and leukemic myeloid cells. Science (Wash. DC). 232:61-65.

26. Palaszynski, E. W., and J. N. Ihle. 1984. Evidence for specific receptors for interleukin 3 on lymphokine-dependent cell lines established from long-term bone marrow cultures. J. Immunol. 132:1872-1878.

27. Walker, F., N. A. Nicola, D. Metcalf, and A. W. Burgess. 1985. Hierarchical down-modulation of hemopoietic growth factor receptors. Cell. 43:269-276.

28. Park, L. S., D. Friend, S. Gillis, and D. L. Urdal. 1986. Characterization of the cell surface receptor for a multi-lineage colony-stimulating factor (CSF-2 $\alpha$ ). J. Biol. Chem. 261:205-210.

29. Guilbert, L. J., and E. R. Stanley. 1980. Specific interaction of murine colony-stimulating factor with mononuclear phagocytic cells. $J$. Cell Biol. 85:153-159.

30. Morgan, C. J., and E. R. Stanley. 1984. Chemical crosslinking of the mononuclear phagocyte-specific growth factor CSF-1 to its receptor at the cell surface. Biochem. Biophys. Res. Commun. 119:35-41.

31. Pigoli, G., A. Waheed, and R. K. Shadduck. 1982. Observations on the binding and interaction of radioiodinated colony stimulating factor with murine bone marrow cells in vitro. Blood. 59:408-420.

32. Shadduck, R. K., G. Pigoli, A. Waheed, C. Caramatti, G. Degliantoni, V. Rizzoli, A. Porcellini, and L. Schiffer. 1983. Identification of hemopoietic cells responsive to colony stimulating factor by autoradiography. Blood. 62:1197-1202.

33. Caramatti, C., G. Pigoli, R. K. Shadduck, and A. Waheed. 1983. The effects of preincubation of bone marrow cells on the binding of colony stimulating factor. J. Lab. Clin. Med. 102:1-16.

34. Chen, B. D.-M., C. Kuhn III, and H.-S. Lin. 1984. Receptormediated binding and internalization of colony-stimulating factor (CSF1) by mouse peritoneal exudate macrophages. J. Cell Sci. 70:147-166.

35. Sherr, C. J., C. W. Rettenmier, R. Sacca, M. F. Roussel, A. T. Look, and E. R. Stanley. 1985. The c-fms proto-oncogene product is related to the receptor for the mononuclear phagocyte growth factor, CSF-1. Cell. 41:665-676.

36. Guilbert, L. J., and E. R. Stanley. 1986. The interaction of ${ }^{125} \mathrm{I}-$ colony-stimulating factor-1 with bone marrow-derived macrophages. $J$. Biol. Chem. 261:4024-4032.

37. Walker, F., and A. W. Burgess. 1985. Specific binding of radioiodinated granulocyte-macrophage colony-stimulating factor to hemopoietic cells. EMBO (Eur. Mol. Biol. Organ.) J. 4:933-939.

38. Park, L. S., D. Friend, S. Gillis, and D. L. Urdal. 1986. Characterization of the cell surface receptor for granulocyte-macrophage colony-stimulating factor. J. Biol. Chem. 261:4177-4183.

39. Gasson, J. C., S. E. Kaufman, R. H. Weisbart, M. Tomonaga, and D. W. Golde. 1986. High-affinity binding of granulocyte-macrophage colony-stimulating factor to normal and leukemic human myeloid cells. Proc. Natl. Acad. Sci. USA. 83:669-673.

40. Nicola, N. A., and D. Metcalf. 1985. Binding of ${ }^{125}$ I-labelled granulocyte colony-stimulating factor to normal murine hemopoietic cells. J. Cell. Physiol. 124:313-321.

41. Broxmeyer, H. E., L. Juliano, A. Waheed, and R. K. Shadduck. 1985. Release from mouse macrophage of acidic isoferritins that suppress hematopoietic progenitor cells is induced by purified $\mathrm{L}$ cell colony stim- 
ulating factor and suppressed by human lactoferrin. J. Immunol. 135: 3224-3231.

42. Wing, E. J., and R. K. Shadduck. 1985. Colony stimulating factor. In Biological Response Modifiers. P. F. Torrence, editor. Academic Press, New York. 219-243.

43. Wing, E. J., A. Waheed, R. K. Shadduck, L. S. Nagle, and B. A Stephenson. 1982. Effect of colony stimulating factor on murine macrophages: induction of anti-tumor activity. J. Clin. Invest. 69:270-276.

44. Moore, R. N., H. S. Larsen, D. W. Horohov, and B. T. Rouse. 1984. Endogenous regulation of macrophage proliferative expansion by colony-stimulating factor induced interferon. Science (Wash. DC). 223: 178-181.

45. Pelus, L. M., H. E. Broxmeyer, J. I. Kurland, and M. A. S. Moore. 1979. Regulation of macrophage and granulocyte proliferation: specificities of prostaglandin E and lactoferrin. J. Exp. Med. 150:277-292.

46. Warren, M. K., and P. Ralph. 1986. Macrophage growth factor CSF-1 stimulates human monocyte production of interferon, tumor necrosis factor, and myeloid CSF. J. Immunol. 137:2281-2285.

47. Ishizaka, Y., K. Motoyoshi, K. Hatake, M. Saito, and F. Takaku. 1986. Mode of action of human urinary colony-stimulating factor. Exp. Hematol. 14:1-8.

48. Metcalf, D., and N. A. Nicola. 1985. Synthesis by mouse peritoneal cells of G-CSF, the differentiation inducer for myeloid leukemia cells: stimulation by endotoxin, M-CSF and multi-CSF. Leuk. Res. 9:35-50.

49. Huebner, K. M., M. Isobe, C. M. Croce, D. W. Golde, S. K. Kaufman, and J. C. Gasson. 1985. The human gene encoding GM-CSF is at 5q 21-q32, the chromosome region deleted in the 5q anomaly. Science (Wash. DC). 230:1282-1285.

50. LeBeau, M. M., C. A. Westbrook, M. O. Diaz, R. A. Larson, J. D. Rowley, J. C. Gasson, D. W. Golde, and C. J. Sherr. 1986. Evidence for the involvement of GM-CSF and fms in the deletion (5q) in myeloid disorders. Science (Wash. DC). 231:984-987.

51. Kindler, V., B. Thorens, S. DeKossodo, B. Allet, J. F. Eliason, D. Thatcher, N. Farber, and P. Vassalli. 1986. Stimulation of hematopoiesis in vivo by recombinant bacterial murine interleukin 3. Proc. Natl. Acad. Sci. USA. 83:1001-1005.

52. Lord, B., G. Molineux, N. G. Testa, M. Kelly, E. Spooncer, and T. M. Dexter. 1986. The kinetic response of haemopoietic precursor cells, in vivo, to highly purified, recombinant interleukin-3. Lymphokine Res. 5:97-104.

53. Metcalf, D., C. G. Begley, G. R. Johnson, N. A. Nicola, A. F. Lopez, and D. J. Williamson. 1986. Effects of purified bacterially-synthesized murine multi-CSF (IL-3) on hemopoiesis in normal adult mice. Blood. 68:46-57.

54. Donahue, R. E., E. A. Wang, D. K. Stone, R. Kamen, G. G. Wong, P. K. Sehgal, D. G. Nathan, and S. C. Clark. 1986. Stimulation of haematopoiesis in primates by continuous infusion of recombinant human GM-CSF. Nature (Lond.). 321:872-875.

55. Broxmeyer, H. E., A. Smithyman, R. R. Eger, P. A. Meyers, and M. DeSousa. 1978. Identification of lactoferrin as the granulocyte-derived inhibitor of colony-stimulating activity production. J. Exp. Med. 148: 1052-1067.

56. Broxmeyer, H. E., M. DeSousa, A. Smithyman, P. Ralph, J. Hamilton, J. Kurland, and J. Bognacki. 1980. Specificity and modulation of the action of lactoferrin, a negative feedback regulator of myelopoiesis. Blood. 55:324-333.

57. Bagby, G. C., Jr., V. D. Regas, R. M. Bennett, A. A. Vandenbark, and H. S. Garewal. 1981. Interaction of lactoferrin, monocytes, and Tlymphocyte subsets in the regulation of steady-state granulopoiesis in vitro. J. Clin. Invest. 68:56-63.

58. Bagby, G. C., Jr., E. McCall, and D. L. Layman. 1983. Regulation of colony stimulating activity production. Interaction of fibroblasts, mononuclear phagocytes and lactoferrin. J. Clin. Invest. 71:340-344.

59. Bagby, G. C., Jr., E. McCall, K. A. Bergstrom, and D. Burger. 1983. A monokine regulates colony stimulating activity production by vascular endothelial cells. Blood. 62:663-668.

60. Broxmeyer, H. E., D. C. Bicknell, S. Gillis, E. L. Harris, L. M.
Pelus, and G. W. Sledge, Jr. 1986. Lactoferrin: affinity purification from human milk and polymorphonuclear neutrophils using monoclonal antibody (II2C) to human lactoferrin, development of an immunoradiometric assay using II2C, and myelopoietic regulation and receptorbinding characteristics. Blood Cells (Berl.). 11:429-446.

61. Gentile, P. S., and H. E. Broxmeyer. 1983. Suppression of mouse myelopoiesis by administration of human lactoferrin in vivo and the comparative action of human transferrin. Blood. 61:982-993.

62. Broxmeyer, H. E., S. Cooper, D. Williams, and P. Gentile. 1984. Influence of purified lactoferrin (LF) in vivo on mouse multipotential (CFU-GEMM), erythroid (BFU-E) and granulocyte-macrophage (CFUGM) progenitor cells. Blood. 64(Suppl. 1):126a. (Abstr.)

63. Shadduck, R. K., A. Waheed, A. Porcellini, V. Rizzoli, and J. Levin. 1980. A method for the removal of endotoxin from purified colony-stimulating factor. Proc. Soc. Exp. Biol. Med. 164:40-50.

64. Quesenberry, P., J. Levin, K. Zuckerman, R. Rencricca, R. Sullivan, and W. Tyler. 1979. Stem cell migration induced by erythropoietin or haemolytic anemia: the effects of actinomycin and endotoxin contamination of erythropoietin preparation. Brit. J. Hematol. 41:253-269.

65. Broxmeyer, H. E., J. Bognacki, P. Ralph, M. H. Dorner, L. Lu, and H. Castro-Malaspina. 1982. Monocyte-macrophage derived acidic isoferritins: normal feedback regulation of granulocyte-macrophage progenitor cells. Blood. 60:595-607.

66. Lu, L., and H. E. Broxmeyer. 1983. The selective influence of hemin and products of erythrocytes on colony formation of human erythroid (BFU-E) and multipotential (CFU-GEMM) progenitor cells in vitro. Exp. Hematol. 11:721-729.

67. Lu, L., and H. E. Broxmeyer. 1985. Comparative influences of phytohemagglutinin-stimulated leukocyte conditioned medium, hemin, prostaglandin $\mathrm{E}$ and low oxygen tension on colony formation by erythroid progenitor cell in normal human bone marrow. Exp. Hematol. 13:989993.

68. Broxmeyer, H. E., D. E. Williams, S. Cooper, A. Waheed, and R. K. Shadduck. 1987. The influence in vivo of murine colony stimulating factor-1 on myeloid progenitor cells in mice recovering from sublethal dosages of cyclosphosphamide. Blood. In press.

69. Broxmeyer, H. E., D. E. Williams, and S. Cooper. 1986. The influence in vivo of natural murine interleukin-3 on the proliferation of myeloid progenitor cells in mice recovering from sublethal dosages of cyclophosphamide. Leuk. Res. In press.

70. Broxmeyer, H. E., G. VanZant, J. R. Zucali, J. LoBue, and A. S. Gordon. 1974. Mechanisms of leukocyte production and release XII. A comparative assay of the leukocytosis-inducing factor (LIF) and the colony stimulating factor (CSF). Proc. Soc. Exp. Biol. Med. 145:12621267.

71. Metcalf, D., and A. W. Burgess. 1982. Clonal analysis of progenitor cell commitment to granulocyte or macrophage production. J. Cell. Physiol. 111:275-283.

72. Metcalf, D., G. R. Johnson, and A. W. Burgess. 1980. Direct stimulation by purified GM-CSF of the proliferation of multipotential and erythroid by purified GM-CSF of the proliferation of multipotential and erythroid precursor cells. Blood. 55:138-147.

73. Emerson, S. G., C. A. Sieff, E. A. Wang, G. G. Wong, S. C. Clark and D. G. Nathan. 1986. Purification of fetal hematopoietic progenitors and demonstration of recombinant multipotential colony stimulating activity. J. Clin. Invest. 76:1286-1290.

74. Kajigawa, S., S. Suda, J. Suda, M. Saito, Y. Miura, M. Ilzuka, S. Kobayashi, N. Minato, and T. Sudo. 1986. A recombinant murine granulocyte/macrophage (GM) colony-stimulating factor derived from an inducer $\mathrm{T}$ cell line (IH 5.5). Functional restriction to GM progenitor cells. J. Exp. Med. 164:1102-1113.

75. Metcalf, D., A. W. Burgess, G. R. Johnson, N. A. Nicola, E. C. Nice, J. DeLamarter, D. R. Thatcher, and J. J. Mermod. 1986. In vitro actions on hemopoietic cells of recombinant murine GM-CSF purified after production in Escherichia coli: comparison with purified native GM-CSF. J. Cell. Physiol. 128:421-431. 